\title{
The Rain Maker
}

\author{
Laci Gross*
}

Department of Fashion Design and Merchandising, Ursuline College, USA

*Corresponding author: Laci Gross, Department of Fashion Design and

Merchandising, Ursuline College, USA.

\author{
Received Date: February 08, 2020 \\ Published Date: February 14, 2020
}

\section{Opinion}

On the bottom floor of the Besse Library and across the Media Center is a room that either most people probably don't pay attention to or always wonder what it contains. The room holds thousands of stories from all over the country, dating from over a century ago to the present day. These stories are not limited to paper and a bound cover but by thread and fabric. They all help create the Historic Costume Study Collection. Upon entering the cold room, you might feel overwhelmed. On the wall to the left are shelves that contain purses, hats, and muffs; on the right, there are shoes, gloves, and jewelry in cabinets and in repurposed library catalog card holders. Of course, you cannot overlook the mountain of garment boxes reaching up to the ceiling. The back wall has the fur and extensive wedding gown sections. Clothing racks are placed in messy rows that make maneuvering around difficult. The Historic Costume Study Collection has all you could ever need and want from fashion. The collection has several individual categories such as: coats, jackets, trousers, skirts, tops, evening wear, and suits. Shifting through the designer racks, you will notice highly respected names such as Chanel, Scassi, Michael Kors, Valentino, Escada, St. John, Missoni, and Christian Dior- just to name a few.

Being the work study student for the fashion department for two years now, I am lucky enough to work frequently with this impressive collection. Part of my job is to tag, file, and remove these expensive and historic pieces every week. I am used to working with vintage designer clothing that is far too valuable for my mind to comprehend. I sometimes stand in the center of the collection and look at all the beautiful garments around me. The room is so silent that I am left alone with nothing but my own thoughts while drowning in a sea of precious clothing. During these times I wonder how this massive collection came to be. What was the motive behind it? Who made it happen? What were the challenges? There is only one person to ask, of course, and that is Dr. Korosec. She is the curator of the Historic Costume Study Collection, chair of the fashion department, one of my professors, and someone I look up to. Working with her for work study and being one of her students really helped develop the close relationship we have today. We bounce ideas off of each other and work together to make the collection the best it can be.

I ask her these questions about the collection in her office on a Monday morning. I sit down in a comfortable chair at her desk while she answers emails and tells me about the recent fashion field trip to Columbus. Out of all the offices I visit on campus, hers is the most unique, glamorous, and crowded. There are a few racks on the side of the room completely full of beaded, jeweled, and sequined gowns for an upcoming gallery show. In the back are more racks of clothes that are yet to be filed away in the collection. On the walls are pictures of her past trip to Africa and her degrees. The room is truly inspiring and arouses my curiosity whenever a certain garment catches my eye.

I first ask the most obvious question, which is how did the collection begin? "In 1984, I began heading up the fashion program at Ursuline College," she explains. "It was a wonderful opportunity that needed leadership. The Vice President for Academic Affairs, Fr. Thomas Chambers, requested to see me one month after I started my work." She remembers how intimidated she was for that meeting, having a priest in uniform, casually sitting across from her. "He pretty much said, 'How's it going?' I replied, 'Your students are asleep!' 'Well, they're yours now; wake them up!' he said. 'I have an idea,' I said. 'What if students could see fashion as I talk about it? Students read it, write it, and hear it - what if they could see it? I would like to roll in a rack and show it as I talk about it." After telling this, she looks at me seriously and begins ticking off her fingers. "And he said the five most dreaded words: 'How much will this cost?' I answered, 'I don't know; it will either fail or succeed 
very quickly. You don't need money to start, you just have to begin.' And so, I did."

Dr. Korosec hesitates a few seconds when I ask her if she had any doubts when the collection first began. Understandably, it would take plenty of work and ambition to turn it into something successful and useful for the fashion classes. Being a fashion student myself, I can't tell how many times we have learned from these beautiful pieces. "Students were bored, anything would have been better than what they were doing," she answers. "I am an animated person, so anything would be better than just giving a lecture. So, I had zero doubts. I'm an innovative thinker, I think outside of the box."

Her initial goals for the collection were to enhance the typical fashion lecture and create more endowed scholarships. Not only has she achieved these goals, she has surpassed them. The fashion program started with only one scholarship, and now it has four. One of the main drives that keep the fashion program going is the community fashion shows. To keep the collection safe, it is not open to the public. However, pieces are put into these fashion shows, so people are able to have a glimpse at the collection. These shows also become opportunities to raise money for endowed scholarships. Originally, the annual fashion show was always held in a common area at 2:00 on a Thursday afternoon and barely anyone attended. When Dr. Korosec was hired, she was shown a video of past fashion shows. "It was hard to watch," she admits while squirming in her seat. "They asked me, 'Can you do better than that?' I said yes. And that's one of the things I changed immediately." The fashion show was changed to a Saturday night at 7:00 and people loved it. Later, it was changed to a Sunday. "I'm not sure who suggested it, but they loved the fact that we were getting people. They thought we could get even more people on Sundays after church, which is so Ursuline-thinking. At that time, we started to charge admission, and all the money goes to the students as scholarships."

"How has the collection changed over the years?" I then ask. "I know it has jumped around quite a bit, so where did it first begin?"

"In a closet," she laughs, "in the hall of Dauby. It's now an office. And then it moved to where this office is." She tells me that in the 1980s, Ursuline had a cooking program, and there were stoves and sinks where the fashion department is today. Her current office was a dining room at the time. When the fashion program grew, the cooking program ended. After temporarily moving the collection to where her current office is, it then moved to a classroom across the hall. "I asked for more space, and it is now on the ground level of Besse Library," she concludes. "And we are now asking for more space." This is the number one challenge to the collection. The problem is not the lack of interest from donors or the public; it's simply the lack of space. Properly filing garments on racks is becoming more difficult because of this issue.

Talking about all this history makes me wonder about the story of the first piece of the collection. I have been lucky enough to have seen it a few times. The garment is a light blue and white $100 \%$ cotton mini dress from the 1960s with a V-neck collar and tie in the back (Figure 1). "Receiving the first dress was 'pure joy,"' Dr. Korosec remembers. "That was the first. After that, word spread like wildfire that this was a home for your favorite dress. In thirtysix years, the collection has grown to 4,000 pieces, making us the 'Best Closet in Cleveland.' The donor who gave us the first piece was so pleased to find a home for her favorite dress." At the time, Dr. Korosec was giving a lecture about fashion and how she was starting the Historic Costume Study Collection. During this, a woman in the audience simply told her that she had a dress that could be put into the collection. The dress still remains in the collection and became a starting point for thousands of items thereafter.

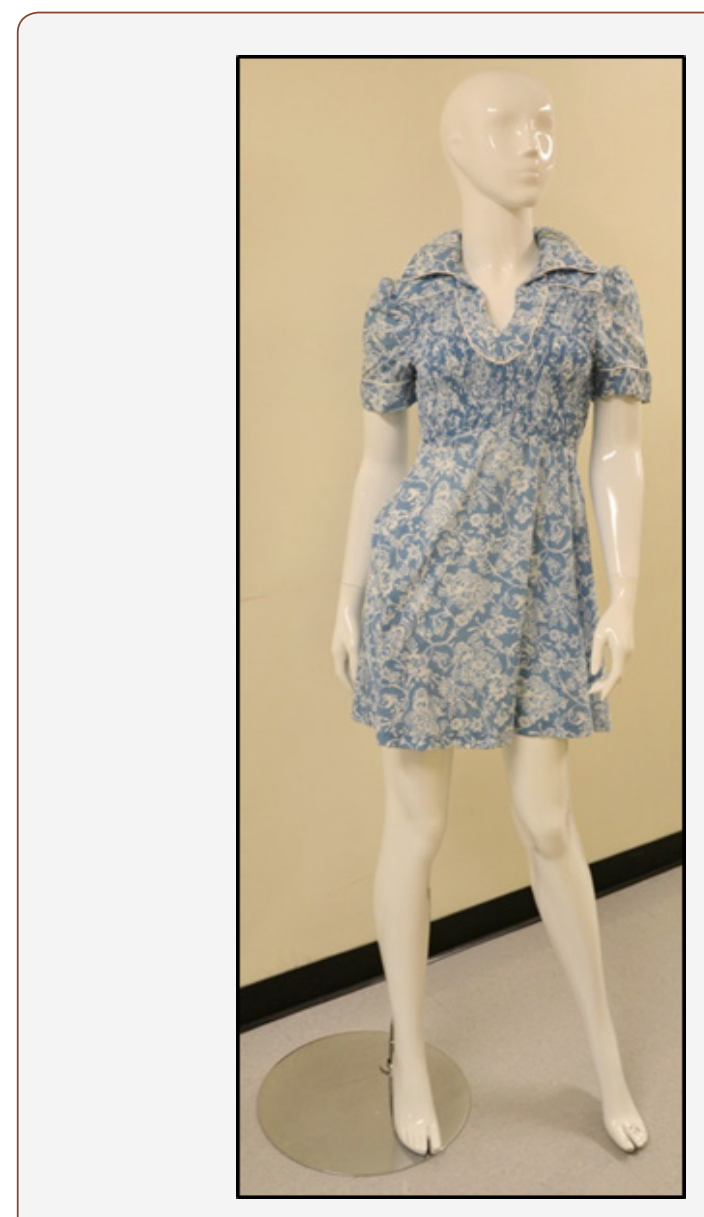

Figure 1: The first piece of the historic costume study collection. (Source: Gary Thomas).

Now we know about the first piece, but what about the oldest piece of the collection? The oldest piece happens to be a striped green silk two-piece ensemble that dates from the Abraham Lincoln period, 1861-1865 (Figure 2). Dr. Korosec eagerly brings the garments from the back of the room over to her desk. Our fingertips brush over the fabric and the intricate stitching. The garments are in amazing condition, beautifully made, with machine and hand stitching. The donor donated it in the spring of 2016. At the time, Dr. Korosec was doing a display at The Country Club, which was celebrating 125 years of being active. The donor, who was the oldest member, had this dress front and center. In time, she gave it to the collection to keep it safe. 


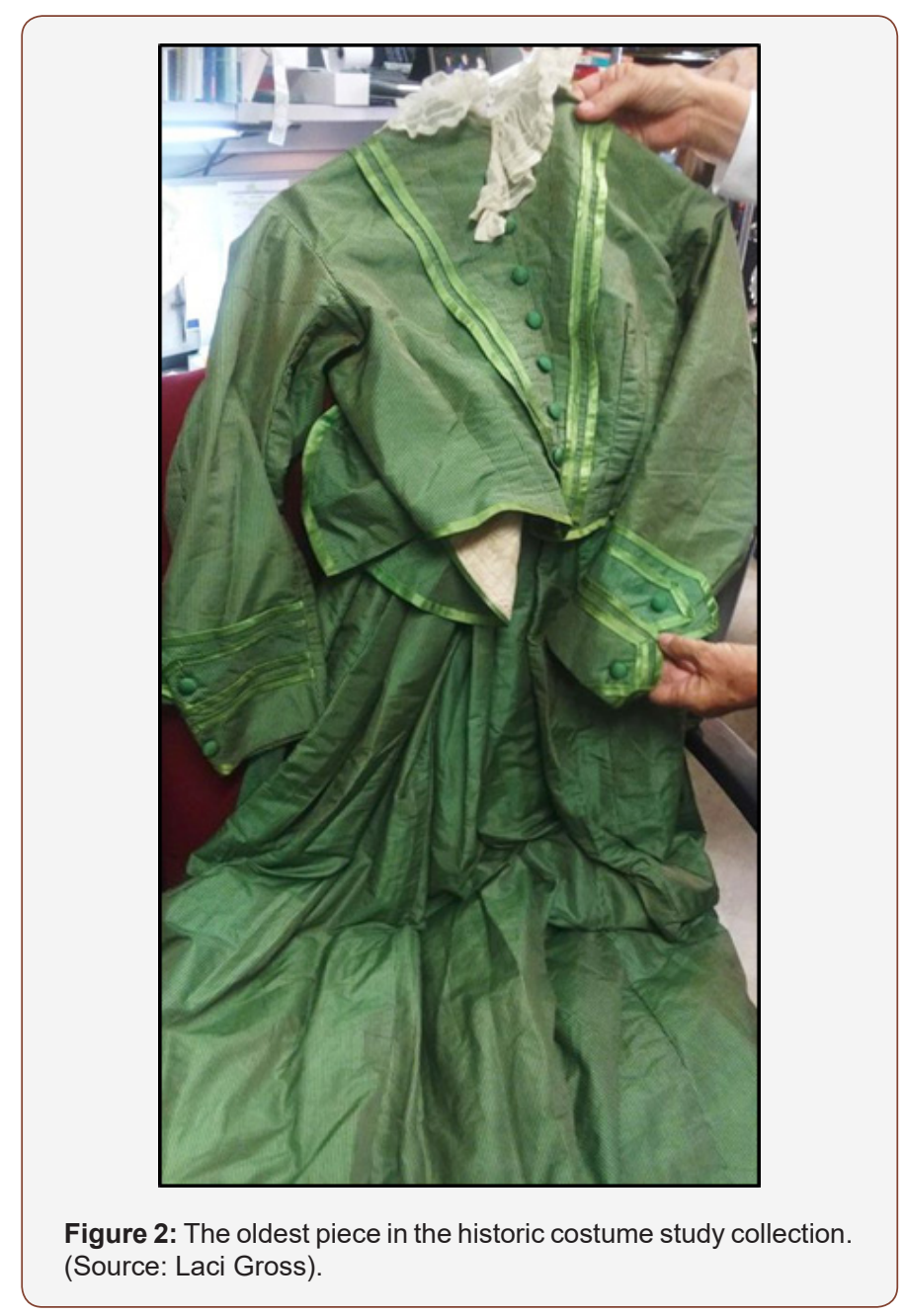

What exactly is the process to donating? After making an appointment to drop off donations, every piece is examined under a microscope for any insects and mildew spores. If the garment has either of these, it cannot be accepted as it could contaminate the entire collection. The second step is that a Deed of Gift is created, and the donor must sign it in order for us to keep it in the collection. My job comes into play when I tag each piece according to the donor's file number, and I put it into the collection. The file number is a way to identify the donor and give recognition to their contribution to the collection. The number also helps to keep the donor's identity private. Sometimes it is necessary to deaccession items. This happens if a piece has become too damaged or if there is a duplicate.

After these questions, I finally ask her with a smile, "So, what is your favorite piece?"

"Oh!" she exclaims and hesitates to answer. "It's hard for me to select my favorite piece because it's like asking me who is my favorite child," she laughs. "I love every single piece equally. Each piece came with a story of someone's life journey. That's why it's so hard."

I then ask about the future of the collection. What is her dream? "That the collection would be housed attached to its own gallery," she answers without even thinking about it. Every chance she gets she tells me about this dream. "We would have monthly fashion exhibits that the students could create. People in the community would come in by the busload to see it. It would be a destination."

“Do you believe you made an impact?" I ask my last question.

"Yes, I have enhanced student learning, learned about donors' oral history of their garments, and enriched the community through exhibits," she answers. She thinks back about everything she has done to get where she is now and what she wants to do for the future. "I was told once that I was a 'true rain maker,' and that has always stuck with me."

\section{Acknowledgement}

None.

\section{Conflict of Interest}

No conflict of interest. 